\title{
Leszek Porębski
}

(Akademia Górniczo-Hutnicza w Krakowie) \section{Główne wymiary wykorzystania Internetu w polityce}

Obywatel - konsument - obserwator

\section{Istota rewolucji informacyjnej i pojęcie elektronicznej demokracji}

Dolityka nie jest jedynym aspektem życia publicznego, w którym można dostrzec wyraźny wpływ technologii informacyjnych i komunikacyjnych (information and communication technologies - ICT). Gwałtowny rozwój ICT w ostatnich dekadach ubiegłego stulecia doprowadził do przemian w sferze gospodarki, mediów, edukacji czy wreszcie w sposobach spędzania wolnego czasu. Najistotniejsze znaczenie miało z tego punktu widzenia oczywiście powstanie i rozpowszechnienie Internetu. W konsekwencji analiza różnych aspektów życia społecznego musi obecnie w coraz większym stopniu uwzględniać cały szereg pojęć dookreślanych kategoriami, takimi jak "elektroniczny" czy "tele”. Elektroniczna poczta, e-handel, e-marketing, telemedycyna czy telepraca to tylko kilka wybranych przykładów.

W sferze polityki terminem, który najsilniej w tym kontekście zadomowił się w języku analityków, jest elektroniczna demokracja. Pojęcie to nie ma jednak w politologii uzgodnionego i powszechnie akceptowanego znaczenia. W literaturze przedmiotu dominują dwa podstawowe podejścia do istoty elektronicznej demokracji. Pierwsze to definicje o charakterze normatywnym. Sugerują one, że demokracja elektroniczna to „lepsza” wersja tradycyjnego modelu demokratycznego. Wykorzystanie nowych 
technologii ma w takim ujęciu zwiększać poziom partycypacji, polepszać efektywność komunikacji politycznej czy zbliżać struktury władzy do obywatela. „Elektroniczna demokracja może być rozumiana jako zdolność do podniesienia przez nowe środowisko komunikacyjne [ICT - L. P.] poziomu i jakości publicznej partycypacji w procesach rządzenia" [Kakabadse et al. 2003: 47]. Definicje tego typu wyznaczają w istocie kierunek wpływu nowych technologii na kształt współczesnej demokracji, traktując elektroniczną demokrację jako kolejny etap w procesie doskonalenia demokratycznego modelu rządzenia.

Bardziej adekwatnym narzędziem opisu oddziaływania ICT na sferę demokracji wydaje się drugi typ definicji. Mają one charakter czysto opisowy i odnotowują samą obecność nowych technologii w różnych aspektach polityki, nie sugerując jednocześnie ostatecznego bilansu owych oddziaływań. „E-demokrację definiujemy jako »użycie technologii informacyjnych w procesach demokratycznych «. Jest to szeroka definicja, wybrana, by stwierdzić, że samo użycie technologii informacyjnych nie implikuje żadnej konkretnej formy demokracji" [Grönlund 2003: 93].

Idąc tym tropem, możemy zdefiniować elektroniczną demokrację jako intensywne i trwałe wykorzystanie technologii informacyjnych i komunikacyjnych jako środka realizacji podstawowych procesów i procedur demokratycznych'. W takim znaczeniu pojęcie elektroniczna demokracja będzie używane w dalszej części tekstu.

\section{Główne wymiary elektronicznej demokracji}

Elektroniczna demokracja jest oczywiście zjawiskiem wieloaspektowym. Jego elementami składowymi są zarówno problemy związane z sieciową mobilizacją polityczną, oddziaływaniem Internetu na sposób funkcjonowania instytucji politycznych, kwestie wykorzystania ICT w procedurach wyborczych, jak i wpływ nowych technologii na relacje obywatela i państwa. Poza sferą tak rozumianej elektronicznej demokracji pozostają natomiast - istotne ze społecznego punktu widzenia - problemy cyfrowego wykluczenia (digital divide) czy dokonujące się pod wpływem nowych

1 Szczegółową analizę relacji pojęcia elektroniczna demokracja i pojęć pokrewnych, a także przegląd różnych definicji e-demokracji można znaleźć w: [Porębski 2001: 35-40]. 
technologii przemiany modelu współczesnego państwa². Są one raczej makrokonsekwencjami wyłaniania się elektronicznej demokracji niż czynnikami wchodzącymi w jej zakres.

Z perspektywy jednostki elektroniczna demokracja oznacza odgrywanie co najmniej kilku istotnych i różnych ról. Trzy spośród nich wydają się mieć najważniejsze znaczenie. Umownie można je określić jako role obywatela, obserwatora i klienta. Zawsze wtedy, gdy za pomocą ICT podejmujemy aktywność związaną z szeroko rozumianą polityczną partycypacją, występujemy jako obywatele - realizujący swe podstawowe w demokracji prawo do kształtowania rzeczywistości politycznej. Dotyczy to, z jednej strony, udziału w sieciowym „czacie” z ważnym politykiem, z drugiej zaś, choćby podpisywania sieciowej petycji w sprawie będącej przedmiotem publicznej debaty. Najistotniejszym aspektem tego wymiaru elektronicznej demokracji jest oczywiście wykorzystywanie Internetu jako środka realizacji procedur wyborczych.

Udział w głosowaniach jest zazwyczaj związany z koniecznością poszukiwania choćby podstawowych informacji pozwalających na podjęcie decyzji wyborczej. W szerszym sensie - zdecydowana większość obywateli to odbiorcy informacji politycznych, a znacząca część spośród nich wykorzystuje do tego celu nowe technologie informacyjne i komunikacyjne. Wszyscy ci, którzy ograniczają swój sieciowy kontakt z polityką do lektury portali informacyjnych lub oglądania dostępnych w Internecie filmów pokazujących polityków w zabawnych sytuacjach, występują w istocie w roli obserwatora. Dla tej grupy ludzi nowe technologie pełnią funkcję uzupełnienia lub zamiennika tradycyjnych mediów, ich kontakt z polityką ma najczęściej charakter bierny.

Trzeci wymiar elektronicznej demokracji dotyczy przede wszystkim relacji jednostki z instytucjami państwa, a bardziej precyzyjnie - ze strukturami administracji publicznej. Część kontaktów tego typu ma charakter incydentalny (konieczność zdobycia pozwolenia na budowę lub wymiana zagubionego paszportu), część stanowią relacje permanentne (coroczne zeznania podatkowe). Generalnie jednak każdy dorosły obywatel musi wchodzić $w$ wiele interakcji z reprezentantami państwa na różnych szcze-

2 Zwłaszcza kwestia cyfrowego wykluczenia (nazywanego też często ubóstwem informacyjnym) doczekała się w ostatnich latach bardzo bogatej analizy. Obszerny przegląd tej problematyki prezentuje Jan van Dijk [2005]. Zob. też np. [Wilson et al. 2003; James 2008]. 
blach i występuje wtedy przede wszystkim w roli klienta lub konsumenta - odbiorcy usług publicznych. Wykorzystanie Internetu jako medium pośredniczącego w kontaktach urzędu i obywateli zmieniło znacząco ich wzajemne relacje, a cała sfera działań tego typu została nazwana elektroniczną administracją lub elektroniczną biurokracją (e-government).

Wyróżnione powyżej role obywatela, obserwatora i konsumenta nie wyczerpują oczywiście całego zakresu zaangażowania jednostki w sferę elektronicznej demokracji. Można wymienić w tym kontekście co najmniej dwa kolejne aspekty udziału w życiu publicznym zapośredniczonego przez ICT. Są to "aktywista" $i$ „,komentator". Ten pierwszy to osoba zaangażowana w działalność ruchów społecznych czy stowarzyszeń wykorzystujących Internet jako podstawowe medium rozpowszechniania własnych idei, a także środek logistycznego wsparcia dla swej działalności. Zjawisko to nazywane często „sieciowym aktywizmem" ma swój wymiar zarówno globalny, jak i wewnętrzny oraz stanowi ważny element obrazu polityki w okresie rewolucji informacyjnej [zob. Earl 2006; Earl, Kimport 2008].

Funkcję komentatorów pełnią z kolei setki osób prowadzących własne blogi na tematy polityki, ludzie niestrudzenie komentujący bieżące wydarzenia na portalach informacyjnych czy uczestniczący w elektronicznych listach dyskusyjnych poświęconych życiu publicznemu ${ }^{3}$ [zob. Ito 2004; Albrecht et al. 2007; Wawrzak-Chodaczek 2008].

Nie bagatelizując roli "komentatorów" i „aktywistów" w elektronicznym krajobrazie współczesnej polityki, trzeba jednak zauważyć, że funkcje te w istotny sposób różnią się od tych opisanych wcześniej. Zakres aktywności politycznej zarówno w formie tradycyjnej, jak i sieciowej jest zdecydowanie ograniczony i dotyczy ciągle niewielkiego odsetka obywateli. Podobnie wygląda sytuacja w odniesieniu do zaangażowania w aktywne komentowanie rzeczywistości politycznej. Tylko stosunkowo nieliczna mniejszość aktywnie uczestniczy w debacie publicznej. Dzieje się tak i w przypadku dyskursu odbywającego się na łamach prasy, radia i telewizji, i w przypadku debaty elektronicznej.

Z tego punktu widzenia status ról obywatela, obserwatora i klienta jest wyraźnie inny. Zdecydowana większość obywateli śledzi - choćby na

${ }^{3}$ Warto na marginesie zwrócić uwagę, że obecnie także aktywni politycy wyjątkowo chętnie wcielają się w rolę komentatorów (zwłaszcza poprzez prowadzenie własnych blogów). Sprawia to, że granica pomiędzy uprawianiem polityki a jej komentowaniem jest coraz bardziej umowna i nieczytelna. 
podstawowym poziomie - wydarzenia w życiu publicznym i politycznym. W chwili obecnej ten typ aktywności ogranicza się zazwyczaj do kontaktu z telewizyjnymi lub radiowymi programami informacyjnymi, ale liczba odbiorców tego typu audycji dowodzi, że ciągle jeszcze możemy mówić o powszechności odgrywania roli obserwatora.

Z kolei rodzaj aktywności związany z pełnieniem zarówno funkcji obywatela, jak i klienta-konsumenta jest na tyle istotny z punktu widzenia systemu demokratycznego, że angażują one ze swej istoty zdecydowaną większość obywateli. Różne formy partycypacji politycznej, a zwłaszcza udział w wyborach, mobilizują w każdym z państw demokratycznych różny odsetek dorosłych mieszkańców. Nawet jednak w krajach o niskim poziomie uczestnictwa politycznego - jak Polska - jest to więcej niż połowa dorosłej populacji. Podobnie w przypadku konsumpcji usług publicznych. Klientami instytucji administracyjnych są w praktyce prawie wszyscy i tylko niewielu może sobie pozwolić na luksus zupełnego braku kontaktów z reprezentantami biurokracji różnych szczebli.

Sytuacja taka sprawia, że także elektroniczna formuła kontaktów z administracją publiczną czy politycznej partycypacji jest skierowana do bardzo szerokich grup obywateli. W konsekwencji to te właśnie aspekty funkcjonowania demokracji sytuują się w centrum przemian systemu politycznego i razem z rolą obserwatora życia politycznego stanowią najmocniej angażujący jednostkę przejaw elektronicznej demokracji.

\section{Dwie dekady elektronicznej demokracji. Próba bilansu}

\subsection{Internet jako narzędzie realizacji partycypacji politycznej}

Jakkolwiek za początek Internetu uznaje się rok 1969, kiedy udało się po raz pierwszy uzyskać połączenie pomiędzy dwoma oddalonymi o wiele kilometrów komputerami, to w kontekście korzystania z sieci przez masowego użytkownika kluczowe znaczenie ma rok 1989. Wtedy opracowano koncepcję i wstępnie uruchomiono World Wide Web, co stało się wstępem do wyjścia sieci poza wąskie kręgi akademickie. Dwie dekady, jakie upłynęły od tego momentu, pozwalają na dokonanie wstępnej oceny wpły- 
wu Internetu na różne sfery życia społecznego, w tym na politykę. Jaki jest więc $w$ chwili obecnej bilans elektronicznej demokracji?

W sferze politycznej partycypacji kluczowe znaczenie ma oczywiście kwestia wykorzystania ICT w procedurach wyborczych. To przy urnie wyborczej jednostka najbardziej wyraźnie objawia się jako obywatel - członek wspólnoty politycznej współdecydujący o jej kształcie. Oczekiwania dotyczące elektronicznych wyborów były więc olbrzymie, zarówno w sensie usprawnienia techniki głosowania, jak i konsekwencji dla kształtu współczesnej demokracji.

Z tej perspektywy dotychczasowe doświadczenia w sferze wykorzystania nowych technologii informacyjnych i komunikacyjnych - a zwłaszcza Internetu - w procedurach wyborczych wydają się więcej niż skromne. Jeśli uznać, że punktem docelowym, pełną realizacją idei elektronicznego głosowania, jest umożliwienie wyborcom oddawania głosu z dowolnego komputera pracującego w sieci ${ }^{4}$, to charakterystyczna jest wyjątkowa ostrożność państw demokratycznych we wprowadzaniu tego typu rozwiązania.

W Stanach Zjednoczonych, kraju, który trudno posądzać o brak innowacyjności w zakresie technologii, eksperymenty z elektronicznym głosowaniem nie wyszły dotychczas poza wybory (czy bardziej precyzyjnie prawybory) organizowane przez poszczególne partie polityczne. Dotyczy to przede wszystkim Partii Demokratycznej, która już w roku 2000 wprowadziła dla swych sympatyków możliwość udziału w prawyborach prezydenckich w stanie Arizona poprzez Internet. To samo rozwiązanie zostało rozwinięte w prawyborach demokratów w kampanii z roku 2008. Tym razem dotyczyło ono wszystkich osób przebywających za granicą. Dla głosujących „na odległość" (poza Internetem istniała możliwość oddania głosu pocztą, za pomocą faxu lub osobiście w lokalach zorganizowanych w wielu krajach) utworzono specjalny okręg wyborczy. W jego ramach wyborcy wyłonili 22 delegatów na krajową konwencję wyborczą Partii Demokratycznej.

Jednocześnie jednak w sferze wyborów organizowanych i autoryzowanych przez instytucje państwa Amerykanie pozostali do chwili obecnej konserwatywni. Jedynym istotnym krokiem w stronę wprowadzenia ICT do procedur wyborczych stało się stopniowe zastępowanie mechanicz-

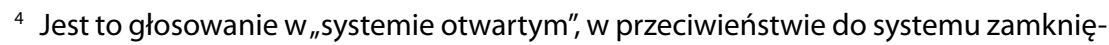
tego, w ramach którego głos można oddać wyłącznie z komputerów udostępnionych przez władze organizujące wybory w sieci specjalnych punktów. 
nych maszyn do głosowania urządzeniami elektronicznymi ${ }^{5}$. Nie zmienia to jednak istoty wyborów $z$ interesującego nas punktu widzenia, ponieważ głosowanie odbywa się w tradycyjnych lokalach wyborczych. Co więcej, powoływani przez władze eksperci zalecali w różnych dokumentach daleko idącą ostrożność w stosunku do idei elektronicznego głosowania - zwłaszcza w systemie otwartym. Pierwszą i najbardziej znaną publikacją tego typu był raport opracowany w styczniu 2000 roku na zlecenie sekretarza stanu w Kalifornii [California Internet 2000].

Mimo upływu czasu zastrzeżenia kierowane pod adresem wyborów przez Internet w systemie otwartym są w większości takie same. Pierwszy problem ma charakter techniczny i dotyczy możliwości zewnętrznej ingerencji w elektroniczny system wyborczy, skutkującej zafałszowaniem rzeczywistych wyników wyborów lub niemożliwością ich ustalenia. Kwestia druga jest związana z procedurą oddawania głosów. Możliwość głosowania z dowolnego komputera pracującego w sieci, a więc także stojącego w prywatnym mieszkaniu, znacząco ogranicza skuteczną kontrolę nad procederem znanym powszechnie jako handel głosami [zob. Gibson 2001].

Warto także zwrócić uwagę na problem, który dotyczy kształtu stratyfikacji społecznej i jest bodaj najistotniejszy z punktu widzenia modelu demokracji. Istnieje silna dodatnia korelacja z jednej strony pomiędzy dostępnością ICT a poziomem dochodu i wykształcenia, z drugiej zaś pomiędzy tymi ostatnimi zmiennymi a poziomem partycypacji politycznej. Wprowadzenie możliwości głosowania przez sieć może doprowadzić do sytuacji, w której pogłębią się znacząco istniejące także i dzisiaj różnice w poziomie partycypacji warunkowane czynnikami socjoekonomicznymi. Nastąpi bowiem radykalne obniżenie kosztów uczestnictwa w procedurach demokratycznych dla osób już dzisiaj znacznie częściej partycypujących, przy niewielkiej zmianie kosztów dla osób, które również w chwili obecnej pozostają na marginesie życia politycznego [Birdsall 2005]. W efekcie realna możliwość korzystania z podstawowych praw politycznych w ramach tego samego społeczeństwa będzie silnie zróżnicowana.

Abstrahując w tym miejscu od szczegółowej oceny adekwatności zastrzeżeń wobec elektronicznego głosowania w systemie otwartym, trze-

${ }^{5}$ W wyborach w roku 2004 już 29\% głosów oddanych było za pomocą elektronicznych terminali wyborczych ustawionych w lokalach wyborczych, a kolejnych $32 \%$ kart było poddanych elektronicznemu skanowaniu. Zob. [Voter's Guide 2004]. 
ba przyjąć, że miały one istotny wpływ na wstrzemięźliwość we wprowadzaniu tej formy uczestnictwa w wyborach. W istocie tylko jedno państwo zdecydowało się na pełne wcielenie w życie otwartego modelu sieciowego głosowania. Krajem tym jest Estonia.

W październiku 2005 roku w wyborach lokalnych, a w lutym 2007 roku w wyborach parlamentarnych obywatele Estonii mieli możliwość oddania głosu drogą elektroniczną - korzystając z dowolnego komputera pracującego w sieci. Głosowanie w sieci było częścią przewidzianego przez estońską ordynację wyborczą „wczesnego głosowania”, przeznaczonego dla osób przebywających poza swym miejscem zamieszkania lub przewidujących wyjazd w dniu wyborów. Wczesne głosowanie odbywa się od 6 do 4 dnia poprzedzającego właściwe wybory.

W wyborach w roku 2007 drogą elektroniczną oddano ponad 30 tysięcy głosów, co stanowiło około $18 \%$ wszystkich głosów oddanych w ramach wczesnego głosowania i 5,4\% wszystkich głosów oddanych w wyborach (w wyborach lokalnych z roku 2005 głosy oddane elektronicznie stanowiły odpowiednio - 7\% głosów oddanych w czasie wczesnego głosowania i 1,87\% wszystkich oddanych głosów). Warto też zwrócić uwagę, że frekwencja w wyborach parlamentarnych w roku 2007 była tylko nieznacznie wyższa niż w poprzednich wyborach z roku 2003 - odpowiednio $61 \%$ i $58 \%{ }^{6}$.

Jednostkowy przypadek Estonii i przytoczone dane nie dają oczywiście wystarczających podstaw do oceny, na ile ewentualne wprowadzenie głosowania przez Internet odmieniłoby oblicze współczesnej demokracji. Wspomniane wcześniej zastrzeżenia i w konsekwencji bardzo skromne doświadczenia w tym zakresie sprawiają, że w chwili obecnej głosowanie w sieci - ten aspekt wykorzystania ICT w polityce, z którym wiązano niewątpliwie największe nadzieje na radykalną przemianę systemu politycznego - pozostaje ciągle niezrealizowanym potencjałem. $W$ tym sensie "obywatel" wciąż czeka na odegranie swej roli w elektronicznej demokracji, a zwolennicy przekształcenia procesów partycypacji politycznej przez nowe technologie mogą czuć się wyraźnie zawiedzeni.

${ }^{6}$ Szczegółową analizę kontekstu, podstaw prawnych, zastosowanych rozwiązań technicznych i przebiegu elektronicznego głosowania w Estonii w czasie wyborów w roku 2005 można znaleźć w: [Madise, Martens 2006], a w roku 2007 w: [Trechsel et al. 2007]. 


\subsection{Internet jako źródło informacji o polityce}

Wykorzystanie Internetu jako źródła informacji o polityce nie wymaga w przeciwieństwie do kwestii ICT w procedurach wyborczych - żadnych decyzji politycznych. Wynika ono wprost z logiki nowych technologii. W tym sensie wymiar elektronicznej demokracji związany z odgrywaniem roli "obserwatora” jest obecny w krajach demokratycznych od momentu rozpowszechnienia sieci jako medium komunikacyjnego.

Wśród wielu treści obecnych w Internecie obecne są oczywiście także te związane ze sferą polityki, co więcej, użytkownicy sieci bardzo chętnie do tego typu materiałów sięgają. Dane dotyczące rynku amerykańskiego (najbardziej interesującego zarówno ze względu na wielkość, jak i zaawansowanie we wdrażaniu ICT) dowodzą, że już w roku 2004 Internet był trzecim spośród najistotniejszych źródeł informacji wyborczej. Do sieci sięgało w tym celu $18 \%$ dorosłych Amerykanów, podczas gdy $69 \%$ wybierało telewizję, a 39\% gazety ${ }^{7}$. Jeśli wziąć pod uwagę, że badania odbyły się mniej więcej w dekadę po pojawieniu się Internetu jako ogólnodostępnego serwisu, to dynamika „podbijania” rynku informacji politycznej przez to medium jest imponująca.

Nadzieje wiązane z siecią jako źródłem informacji o polityce dotyczyły jednak nie tyle samej popularności Internetu, ile przekonania, że będzie on stanowił istotną alternatywę pod względem dostarczanych treści. $Z$ tego punktu widzenia sytuacja jest zdecydowanie bardziej skomplikowana. Oczywiście w sieci można znaleźć bardzo bogatą ofertę informacji i opinii dotyczących polityki. Wszelkiego rodzaju źródła niezależne: portale poświęcone konkretnym zagadnieniom, witryny stowarzyszeń i organizacji, wreszcie inicjatywy pojedynczych osób - wszystkie one obecne są w Internecie i jest to dla tego typu przedsięwzięć podstawowy (i zazwyczaj jedyny) kanał rozpowszechniania. Sprawia to, że osoba zainteresowana ma możliwość przyglądania się polityce $z$ wielu różnych perspektyw, budując jednocześnie znacznie bogatszy obraz życia publicznego.

W tym sensie można mówić o spełnieniu nadziei i postulatów zwolenników elektronicznej demokracji. Debata publiczna została wzbogacona, uczestniczy w niej znacznie większa liczba podmiotów niż wcześniej,

${ }^{7}$ Respondenci mogli wskazywać więcej niż jedno źródło. W tym samym badaniu czwartą pozycję - tuż za Internetem - zajęło radio, uzyskując 17\% wskazań [Rainie et al. 2005]. 
a tradycyjne media straciły swój monopol na kształtowanie obrazu sfery polityki, czy szerzej - życia społecznego. Internet stał się sposobem na przekształcenie istniejącej dotychczas formuły opisu rzeczywistości politycznej. Do momentu rozpowszechnienia ICT była ona zamknięta (zdominowana przez medialnych gigantów), w chwili obecnej stała się otwarta (umożliwia wejście w publiczny obieg informacyjny treści firmowanych przez dowolną osobę).

Jeśli jednak spojrzeć na tę samą kwestię nie z perspektywy podaży, lecz popytu na informacje, ogólny obraz ulega diametralnej zmianie. Debata publiczna to nie tylko dostępność wielu alternatywnych źródeł informacji. To także, a może przede wszystkim, motywacja do ich wykorzystywania. $Z$ tego punktu widzenia bilans obecności nowych mediów w życiu publicznym może zostać uznany za rozczarowujący.

Dostępne badania wskazują, że najchętniej odwiedzanymi przez Amerykanów sieciowymi źródłami informacji wyborczej są kolejno: portale informacyjne gigantów, takich jak Google czy Yahoo, witryny ogólnokrajowych sieci telewizyjnych i witryny lokalnych mediów komercyjnych. Dopiero na kolejnych miejscach w tej klasyfikacji pojawiają się pierwsze alternatywne w stosunku do komercyjnego rynku medialnego źródła. Są nimi witryny władz lokalnych (miejsce piąte), witryny grup feministycznych, ekologicznych itp. (miejsce szóste) czy blogi polityczne (miejsce siódme). Popularność tych ostatnich jest jednak porównywalna z witrynami mediów zagranicznych czy informacyjnych portali satyrycznych. Co więcej, różnice w popularności pomiędzy poszczególnymi kategoriami źródeł są bardzo wyraźne. O ile na strony portali informacyjnych i witryny ogólnokrajowych telewizji komercyjnych zagląda w poszukiwaniu informacji wyborczych po $60 \%$ respondentów, to na witryny władz lokalnych tylko $28 \%$, a na witryny niezależnych organizacji obywatelskich (ekolodzy, feministki itp.) 24\% [Rainie, Horrigan 2007].

Przytoczone badania dotyczą kampanii wyborczej z roku 2006, ale ogólna tendencja utrzymuje się od wielu lat. Nic też nie wskazuje na to, by sieciowi obserwatorzy życia politycznego stosowali inne wzorce zachowań w sytuacjach wyborczych niż w odniesieniu do codziennej polityki.

Przeciętny użytkownik sieci, korzystający z dostępnych w niej zasobów politycznych, ogranicza się w świetle przytoczonych wyników do sięgania po znane już sobie doskonale kanały dystrybucji informacji działa- 
jące według logiki rynkowej. Debata publiczna jest więc $w$ istocie ciągle zdominowana przez tych samych aktorów, nie tyle z powodu bezalternatywności komercyjnych źródeł informacji - jak w okresie przed rozpowszechnieniem ICT - ile z powodu wierności odbiorców wobec tradycyjnych nadawców.

Rola sieciowego obserwatora życia publicznego jest więc w sensie przyswajanych treści odgrywana przez przeniesienie znanych już wzorców w nową, wirtualną scenerię. Zapoznawanie się z artykułem z prasy bulwarowej na temat zdrady małżeńskiej znanego polityka lub oglądanie swojego ulubionego telewizyjnego programu informacyjnego $\mathrm{w}$ formie sieciowej nie stanowi nowej jakości w opisie współczesnej polityki.

Dosyć powszechnie uznaje się, że mediatyzacja polityki - a więc poddanie jej logice komercyjnych mediów - to przejaw kryzysu współczesnej demokracji, a nie jej siły [zob. Meyer 2002]. W tym kontekście opisany model wykorzystywania sieci jako źródła informacji politycznej oznacza utrwalenie negatywnych wzorców, co więcej, w bardziej atrakcyjnym, dostępnym w każdej chwili i dostosowanym do indywidualnych preferencji kształcie. Wymiar elektronicznej demokracji związany z odgrywaniem roli obserwatora jest więc już wyraźnie obecny we współczesnej demokracji, tyle że zamiast przekształcać zastany model życia publicznego, poddaje go skutecznej petryfikacji.

\subsection{Internet jako środek realizacji usług publicznych}

Biurokracja stanowi istotny element aparatu państwa już co najmniej od XVIII wieku ${ }^{8}$. Dopiero jednak radykalna rozbudowa socjalnych funkcji państwa, jaka nastąpiła w Europie po zakończeniu drugiej wojny światowej (prowadząc do powstania „państwa opiekuńczego"), uczyniła z relacji jednostki z reprezentującymi państwo strukturami administracyjnymi ważny aspekt współczesnej demokracji. Dla przeciętnego obywatela uosobieniem abstraktu, jakim jest pojęcie państwa, jest bardzo często urzędnik, z którym kontakt jest nieodzowny dla realizacji wielu różnych celów i potrzeb. W tego typu kontaktach jednostka występuje zazwyczaj w roli klienta-konsumenta usług publicznych.

\footnotetext{
${ }^{8}$ Na temat genezy współczesnego modelu biurokracji zob. [Malec 2007].
} 
Rewolucja informacyjna i rozpowszechnienie ICT pozwoliły na silne przekształcenie wzajemnych relacji obywatela i instytucji państwa, poprzez przeniesienie ich punktu ciężkości ze świata realnego w cyberprzestrzeń. Ten aspekt wykorzystania nowych technologii w demokratycznym systemie politycznym zwany jest zazwyczaj elektroniczną administracją lub elektroniczną biurokracją. Z perspektywy sposobu realizacji dystrybucji usług publicznych pojęcie elektroniczna administracja obejmuje co najmniej kilka elementów. Można je zarazem w uproszczeniu uznać za etapy zaawansowania na drodze do pełnego przeniesienia relacji jednostka (klient-konsument)-państwo do sfery wirtualnej.

Nie istnieje jeden, powszechnie akceptowany model opisujący poziom rozwoju elektronicznej administracji ${ }^{9}$. Jednym z najciekawszych jest propozycja opracowana przez firmę doradczą Capgemini w ramach badań realizowanych na zlecenie Komisji Europejskiej i dotyczących krajów członkowskich Unii Europejskiej [The User Challenge 2007] ${ }^{10}$. Koncepcja ta przyjmuje pięć głównych etapów zaawansowania e-administracji.

Za poziom podstawowy uznaje się stadium informacyjne. Oznacza ono dostępność na witrynie organów administracji publicznej lub samorządu terytorialnego podstawowych informacji o ich funkcjonowaniu, także tych, które są istotne z punktu widzenia odbiorcy usług publicznych. Chodzi tu więc o informacje na temat podziału kompetencji pomiędzy poszczególne jednostki urzędu, ale także np. udostępnienie na witrynie urzędu podstawowych dokumentów uchwalanych przez władze publiczne danego szczebla.

Kolejny etap to faza interakcji jednostronnej. W przeciwieństwie do etapu poprzedniego, użytkownik ma możliwość nie tylko zapoznania się z informacjami, ale także zadania pytania urzędnikowi, wypowiedzenia się na temat funkcjonowania urzędu, czy wreszcie - co najistotniejsze pobrania z sieci formularza urzędowego. Trzeci poziom zaawansowania e-administracji - faza interakcji dwustronnej - oznacza możliwość przesłania wypełnionych formularzy urzędowych drogą elektroniczną.

${ }^{9}$ Analizę poziomu zaawansowania elektronicznej administracji prowadzi - niezależnie od siebie i według różnych metodologii - wiele instytucji badawczych. Zazwyczaj są to publikacje periodyczne, odnotowujące dynamikę zmian w zakresie rozpowszechniania procedur elektronicznej administracji. Zob. [Leadership 2005; Holzer, Kim 2008; United Nations 2008].

10 Publikacja z roku 2007 jest prezentacją siódmego, corocznego pomiaru poziomu zaawansowania elektronicznej administracji w krajach UE. 
Etap czwarty to faza transakcyjna. Na tym poziomie całość interakcji klient-instytucja publiczna zostaje przeniesiona do sieci, a cała procedura urzędowa odbywa się przez Internet. $Z$ tej perspektywy kluczowe znaczenie ma zwłaszcza możliwość dokonywania w sieci wszelkich opłat administracyjnych, porządkowych itp., będących częścią procesu załatwiania sprawy. Dzieje się to przy wykorzystaniu specjalnych serwisów udostępnionych na witrynach władz publicznych.

Piąta, najbardziej zaawansowana, faza rozwoju elektronicznej administracji to stadium personalizacji. Na tym etapie struktury biurokratyczne same informują konsumenta drogą elektroniczną o konieczności złożenia jakiegoś formularza, automatycznie wypełniają te dane, które już znajdują się w bazie urzędu, prezentują różne scenariusze załatwienia konkretnej sprawy przez klienta itd. Tak rozumiana personalizacja oznacza też konieczność silnej koordynacji działań różnych instytucji publicznych w celu optymalizacji procesu obiegu danych i dokumentów oraz minimalizacji konieczności osobistego udziału konsumenta.

Osiągnięciu każdego z opisanych etapów autorzy badań przypisali określoną wartość liczbową. Przyjęto, że pełna realizacja fazy informacyjnej to $20 \%$ zaawansowania elektronicznej administracji, jednostronna interaktywność to $40 \%$, interaktywność dwustronna - 60\%, transakcyjność - 80\%, a pełną realizację ideału e-administracji (a więc wartość 100\%) zapewnia całkowita personalizacja funkcjonowania struktur administracji publicznej.

Tematyka i objętość tego tekstu nie pozwalają na szczegółową prezentację danych empirycznych analizujących stopień zaawansowania poszczególnych krajów na drodze do realizacji przedstawionego powyżej modelu. Warto tylko zwrócić uwagę, że według ostatniego raportu średni poziom zaawansowania serwisów administracji elektronicznej dla 27 krajów członkowskich UE w roku 2007 wynosił 76\% [The User Challenge 2007: 14]. Oznacza to bardzo wyraźne zbliżenie się do pełnej realizacji poziomu transakcyjnego w codziennym funkcjonowaniu administracji publicznej.

Z punktu widzenia jednostki - konsumenta usług publicznych rozwój elektronicznej administracji to zupełnie nowa jakość w jego relacjach z instytucjami państwowymi i samorządowymi. Wyraża się to w co najmniej trzech wymiarach. Najbardziej wymiernym i namacalnym aspektem jest radykalna redukcja kosztów ponoszonych przez klienta w związku z załatwianiem spraw urzędowych. Możliwość sprawdzenia wszelkich informa- 
cji w sieci i choćby tylko wydrukowania umieszczonego w Internecie formularza oznacza wymierną oszczędność czasu. Co więcej, administracja jest dostępna przez całą dobę i nawet $w$ dni wolne od pracy. W przypadku osiągnięcia pełnej fazy transakcyjnej oznacza to, że czas i energia, jakie należy zainwestować $w$ kontakty $z$ instytucjami państwa, spadają w stopniu trudnym do wyobrażenia przed rozpowszechnieniem się nowych technologii.

Kwestia redukcji kosztów i uczynienia urzędu bardziej przyjaznym dla klienta wiąże się z problemem znacznie szerszym. Rozpowszechnienie modelu elektronicznej administracji powoduje w sposób nieunikniony silne upodmiotowienie jednostki wobec instytucji państwa. Tradycyjna biurokracja była skoncentrowana przede wszystkim na przestrzeganiu własnych procedur, a klienta (czy jak to określano - petenta) i jego potrzeby traktowano jako rodzaj ostatniego ogniwa w "ciągu technologicznym” nastawionym głównie na implementację polityki państwa. U podstaw idei biurokracji elektronicznej leży nastawienie na satysfakcję konsumenta usług publicznych i elastyczne reagowanie na jego zmieniające się potrzeby i oczekiwania. „Z perspektywy klienta kryteria takie, jak wydajność i skuteczność aktywności władz publicznych zyskują na znaczeniu. To zaś oznacza, że proces dostarczania usług publicznych i orientacja na klienta stanęły w centrum uwagi instytucji publicznych" [Lips 1998: 329]. Wykorzystanie ICT jest silnym bodźcem przesuwającym sposób działania struktur administracyjnych w tym właśnie kierunku. Postawa paternalistyczna zostaje zredukowana na rzecz podmiotowego traktowania konsumenta.

Z perspektywy funkcjonowania demokracji istotna jest jeszcze jedna konsekwencja rozpowszechnienia nowych technologii w aktywności struktur administracyjnych. Przeniesienie interakcji klient-urząd do sfery wirtualnej w sposób nieunikniony powoduje zwiększenie stopnia przejrzystości działań biurokracji. Konsument usług publicznych ma stały i nieograniczony dostęp do znacznie szerszego zakresu informacji. Co więcej, także część procedur przetwarzania danych i wypracowywania decyzji, wcześniej wyłączona spod zewnętrznej kontroli i rozgrywająca się wewnątrz izolowanego od postronnych systemu, staje się dostępna dla klienta. Oczywiście, nie pozostaje to bez wpływu na ogólny poziom kontroli obywatela nad instytucjami publicznymi, co jest jednym z istotnych kanonów demokratycznego państwa. Upowszechnienie modelu elektronicznej administracji znacząco zmienia więc krajobraz współczesnej de- 
mokracji, a zwłaszcza pozycję zajmowaną przez jednostkę w relacji do struktur państwa.

\section{W kierunku demokracji konsumenckiej?}

Każdy z omówionych aspektów elektronicznej demokracji akcentuje inny wymiar politycznej aktywności, implikuje więc określony kierunek przemian systemu demokratycznego. Za każdą z koncepcji - symbolizowanych przez pojęcia „obywatel", ,konsument" $i$ „,obserwator" - stoi w istocie odmienna wizja demokracji.

Wykorzystanie nowych technologii informacyjnych i komunikacyjnych w procedurach wyborczych stymuluje rozwój demokracji w wersji partycypacyjnej. Pojęcia takie, jak „elektroniczna Agora” - często używane przez entuzjastów stosowania ICT w celu wzmocnienia różnych form politycznej partycypacji - dobrze oddają klimat tej właśnie koncepcji. Szeroki udział obywateli w procesach wyłaniania ciał przedstawicielskich, a w wersji bardziej radykalnej - także bezpośrednio w procesie decyzyjnym - jest w tym modelu uznawany za kwintesencję dojrzałej demokracji i główny miernik jakości jej funkcjonowania.

W sensie technicznym wizja przeniesienia znaczącej części procesu podejmowania decyzji w państwie na obywateli wykorzystujących do tego celu nowe technologie (głównie Internet) nie wydaje się całkowicie nierealna. Jeżeli w sieci już dziś mogą odbywać się wybory parlamentarne, to nic nie stoi na przeszkodzie, by w przyszłości organizować „elektroniczne referenda" jako stałą formę podejmowania większości istotnych decyzji politycznych. Abstrahując w tym miejscu od oceny, na ile w ramach takiego systemu możliwe byłoby kreowanie racjonalnych i odpowiedzialnych rozstrzygnięć, trzeba jednak uznać, że realizacja opisanego modelu wychodziłaby naprzeciw ideałowi powszechnej partycypacji w stopniu nieosiągalnym dla demokracji współczesnej.

Pełnienie funkcji obserwatora, a więc traktowanie sieci jako źródła informacji o życiu politycznym, w naturalny sposób wysuwa na pierwszy plan nie proces partycypacji, ale raczej podstawowe znaczenie debaty publicznej. Szeroki wachlarz alternatywnych źródeł informacji dostępnych w sieci jest w tym kontekście bodźcem do wzbogacenia sfery publicznej i wyrwania jej z dominacji komercyjnych mediów. Oznacza to w konse- 
kwencji przesunięcie akcentu życia politycznego w stronę procesu wypracowywania stanowisk wobec kluczowych kwestii, rozważania różnych punktów widzenia i poszukiwania punktów wspólnych. Na pierwszym planie pojawia się więc deliberatywny aspekt demokracji.

Do pełnego rozwoju demokracji deliberatywnej konieczne jest spełnienie dwóch podstawowych warunków. Pierwszym z nich jest nieskrępowany dostęp do informacji, dający możliwość zbudowania własnej opinii na temat kwestii politycznych i poznania stanowisk alternatywnych. Drugi niezbędny element to przestrzeń dla efektywnej komunikacji pomiędzy uczestnikami dyskursu publicznego - arena do wymiany poglądów i dochodzenia do uzgodnień prowadzących w konsekwencji do konkretnych decyzji politycznych.

Rewolucja informacyjna dostarczyła technicznych narzędzi do realizacji obydwu wspomnianych czynników konstytuujących demokrację deliberatywną. W chwili obecnej istnieją zarówno możliwości łatwego zdobycia wszelkich informacji koniecznych do świadomego obserwowania życia publicznego, jak i - w efekcie - ożywienia politycznej debaty oraz nadania jej racjonalnego charakteru. Oba te procesy doskonale mieszczą się w logice Internetu. Jest on więc forum umożliwiającym pełną realizację deliberatywnego modelu demokracji.

Bilans dokonań poszczególnych aspektów elektronicznej demokracji dokonany w poprzedniej części tekstu dowodzi, że ani procesy politycznej partycypacji, ani kształt debaty publicznej nie zostały dotychczas skutecznie odmienione dzięki wykorzystaniu ICT. Trudno więc mówić o znaczącym nasyceniu współczesnej demokracji czynnikiem partycypacyjnym czy deliberatywnym.

Z perspektywy realnej zmiany pozycji jednostki w systemie politycznym najsilniejszy wpływ nowych technologii jest widoczny w sferze zwanej elektroniczną administracją - związanej w rolą "konsumenta”. Co to jednak oznacza w kontekście przekształceń systemu demokratycznego? Jaki model demokracji wyłania się z dotychczasowych - udanych - doświadczeń w zakresie wykorzystania sieci do kontaktów obywatela z instytucjami państwa?

Rozwój elektronicznej administracji nie zmienia oczywiście znaczenia podstawowych procedur demokratycznych, związanych z wyłanianiem ciał przedstawicielskich. Na pierwszy plan wysuwają się jednak sfera dostępu do usług publicznych, ich efektywna dystrybucja i w kon- 
sekwencji zaspokojenie maksymalnie szerokiego zakresu potrzeb. Obywatele nie przestają wybierać deputowanych czy radnych, ale rozliczają ich przede wszystkim ze skuteczności w dostarczaniu świadczeń i dóbr będących w dyspozycji państwa. Polityka staje się rodzajem logistycznego „oprzyrządowania” dla procesu dystrybucji usług publicznych, a państwo to głównie instytucja odpowiedzialna za efektywność tego procesu. Prawo do wpływania na personalny skład elit pełniących kluczowe funkcje polityczne i kierunek realizowanej przez nie polityki sprowadzają się do prawa wyboru najskuteczniejszej strategii zarządzania sferą usług publicznych.

Taki kształt funkcjonowania państwa bywa nazywany demokracją konsumencką i to właśnie ten model polityczny jest w chwili obecnej najsilniej stymulowany przez rewolucję informacyjną. Jak ujęła istotę tego procesu Christine Bellamy [2000: 40]: „demokracja konsumencka ma na celu nie tyle stworzenie wyzwania dla pogrążonych w kryzysie instytucji przedstawicielskich, lecz raczej ich ominięcie. W rezultacie próbuje się przenieść punkt ciężkości demokracji ze sfery politycznej, stworzonej głównie wokół procesów parlamentarnych i wyborczych, w sferę konsumencką, stworzoną głównie wokół procesu konsumpcji usług publicznych". Dzięki nowym technologiom informacyjnym i komunikacyjnym obywatel uzyskał znacznie silniejsze narzędzia egzekwowania swych praw w zakresie konsumpcji dóbr publicznych niż w sferze partycypacji politycznej. „Innymi słowy, konsumeryzm próbuje ograniczyć potęgę i zakres państwa administracyjnego nie poprzez odtworzenie społeczeństwa obywatelskiego tworzonego przez homo publicus, ale starając się rozszerzyć sferę funkcjonowania homo economicus" [Bellamy 2000].

To właśnie w dziedzinie elektronicznej administracji udało się znacznie silniej przełamać dominujące wcześniej wzorce niż np. w odniesieniu do debaty publicznej. Konsument dóbr publicznych wzmocnił swą rolę wobec instytucji państwowych, obserwator życia politycznego ciągle bardziej pozostaje biernym świadkiem debaty publicznej niż jej aktywnym uczestnikiem. Ujmując rzecz obrazowo - chętnie płacimy w Internecie podatki, mandaty za nieprawidłowe parkowanie i sprawdzamy etap załatwiania pozwolenia na budowę domu. Później jednak, zamiast brać udział w sieciowej dyskusji o priorytetach polityki społecznej i komentować niezależny raport ekspertów na temat polityki zagranicznej, śledzimy witryny telewizyjnych kanałów informacyjnych czy elektroniczne wydania 
znanych nam od lat gazet. Obywatel staje się w coraz większym stopniu konsumentem usług dostarczanych przez państwo (zarówno na szczeblu centralnym, jak i na poziomie samorządu lokalnego) i obrazu życia publicznego kreowanego przez komercyjne media.

Tego rodzaju konstatacja brzmi niewątpliwie paradoksalnie w świetle nadziei, z jakimi witano wykorzystanie ICT w sferze polityki. Szereg dokumentów powstałych zwłaszcza w pierwszych latach po pojawieniu się Internetu z entuzjazmem i swoistym poczuciem misji wieszczył powrót „złotej ery" demokracji. Autorzy tego typu tekstów reprezentowali różne pozycje ideowe - zaczynając od radykalnego libertarianizmu, na koncepcjach ze sfery demokracji plebiscytarnej kończąc ${ }^{11}$. Trudno było jednak w tym momencie przyjąć, że realny wpływ nowych technologii na kształt demokracji będzie widoczny przede wszystkim w postaci wzmocnienia elementów demokracji konsumenckiej. Ta ostatnia oznacza przecież $\mathrm{w}$ istocie osłabienie roli odgrywanej w życiu publicznym przez politykę rozumianą jako autonomiczna sfera funkcjonowania zbiorowości, kierująca się swą własną - skierowaną na dobro wspólne - logiką. Demokracja konsumencka to poddanie życia publicznego regułom typowym dla zarządzania i ekonomii, redukcja polityki do roli istotnego, ale tylko jednego spośród wymiarów komercyjnego rynku. W żadnym wypadku nie oznacza to powrotu do źródeł klasycznego sytemu demokratycznego, jest raczej równoznaczne z popchnięciem go na nową - nie do końca rozpoznaną ścieżkę rozwojową. W tym sensie kierunek wpływu Internetu na sferę polityki w pierwszych dekadach rewolucji informacyjnej zdecydowanie odbiega od formułowanych wcześniej przewidywań.

W chwili obecnej trudno przesądzić, na ile opisane tendencje mają charakter stały, a na ile możliwe jest jeszcze odwrócenie trendów. Obecność ICT w różnych aspektach życia politycznego będzie w przyszłości niewątpliwie ulegać wzmocnieniu. Co więcej, trudno wykluczyć pojawienie się zupełnie nowych form wykorzystania technologii informacyjnych i komunikacyjnych w życiu publicznym. Dotychczasowe doświadczenia nie rozstrzygają więc w żadnym przypadku kwestii docelowego kształtu

${ }^{11}$ Dobrym przykładem nawiązania do libertarianizmu w wersji elektronicznej jest słynna Deklaracja Niepodległości w cyberprzestrzeni autorstwa Johna Perry'ego Barlowa [1996], która doczekała się już szeregu akademickich analiz [zob. Winner 1997; Morrison 2009]. Z kolei wizję elektronicznej demokracji plebiscytarnej prezentuje choćby Lawrence Grossman [1995]. 
elektronicznej demokracji. Uczą natomiast niewątpliwie pokory w kwestii przewidywania kierunku wpływu rozwoju technologicznego na obraz życia społecznego.

\section{Bibliografia}

Albrecht Steffen, Lübcke Maren, Hartig-Perschke Rasco. 2007. Weblog Campaigning in the German Bundestag Election 2005. „Social Science Computer Review” vol. 25 , no. 4 , s. 504-520.

Bellamy Christine. 2000. Modelling Electronic Democracy: Towards Democratic Discourses for an Information Age. [w:] J. Hoff, I. Horrocks (red.). Democratic Governance and New Technology. New York: Routledge.

Dijk van Jan. 2005. The Deepening Divide. Inequality in the Information Society. London: Sage.

Earl Jennifer. 2006. Pursuing Social Change Online. „Social Science Computer Review" vol. 24, no. 3, s. 362-377.

Earl Jennifer, Kimport Katrina. 2008. The Targets of Online Protest. „Information, Communication and Society" vol. 11, no. 4, s. 449-472.

Gibson Rachel. 2001. Elections Online: Assessing Internet Voting in Light of the Arizona Democratic Primary. „Political Science Quarterly” vol. 116, no. 4, s. 561$-583$.

Grossman Lawrence. 1995. The Electronic Republic. New York: Viking.

Grönlund Åke. 2003. E-democracy: in Search of Tools and Methods for Effective Participation. „Journal of Multi-Criteria Decision Analysis” vol. 12, s. 93-100.

James Jeffrey. 2008. Digital Divide Complacency: Misconceptions and Dangers. "The Information Society" vol. 24, no. 1, s. 54-61.

Kakabadse Andrew, Kakabadse Nada, Kouzmin Alexander. 2003. Reinventing the Democratic Governance Project through Information Technology? A Growing Agenda for Debate. „Public Administration Review” vol. 63, no. 1, s. 44-60.

Lips Miriam. 1998. Reorganizing Public Service Delivery in an Information Age. [w:] I. Snellen, W. van de Donk (red.). Public Administration in an Information Age. Amsterdam: IOS Press.

Madise Ülle, Martens Tarvi. 2006. E-voting in Estonia 2005. The First Practice of Country-wide Binding Internet Voting in the World. [w:] R. Krimmer (red.). Electronic Voting Proceedings of the 2nd International Workshop Co-organized by Council of Europe, ESF TED, IFIP WG 8.5 and E-Voting.CC. Bregenz. 
Malec Jerzy. 2007. Historyczne modele rozwoju biurokracji. [w:] K. Zuba (red.). Biurokracja. Fenomen władzy politycznej w strukturach administracyjnych. Toruń: Wydawnictwo Adam Marszałek.

Meyer Thomas. 2002. Media Democracy: How the Media Colonize Politics. Cambridge: Polity.

Morrison Aimee Hope. 2009. An Impossible Future: John Perry Barlow's 'Declaration of the Independence of Cyberspace'. „New Media \& Society” vol. 11, no. 1-2, s. 53-71.

Porębski Leszek. 2001. Elektroniczne oblicze polityki. Demokracja, państwo, instytucje polityczne w okresie rewolucji informacyjnej. Kraków: AGH.

The User Challenge. Benchmarking the Supply of Online Public Services. 2007. Directorate General for Information Society and Media, September 2007.

Wawrzak-Chodaczek Mirosława. 2008. Blogi jako forma komunikacji w Internecie. [w:] M. Wawrzak-Chodaczek (red.). Komunikacja społeczna w świecie wirtualnym. Toruń: Wydawnictwo Adam Marszałek.

Wilson Kenneth, Wallin Jennifer, Reiser Christa. 2003. Social Stratification and the Digital Divide. „Social Science Computer Review” vol. 21, no. 2, s. 133-143.

Winner Langdon. 1997. Technology Today: Utopia or Dystopia?. „Social Research” vol. 64 , no. 3, s. 989-1001.

\section{Źródła internetowe}

Barlow John Perry. 1996. A Declaration of the Independence of Cyberspace. http:// homes.eff.org/ barlow/Declaration-Final.html, 5.05.2009.

Birdsall Stephanie. 2005. The Democratic Divide. „First Monday” vol. 10, no. 4. http:// firstmonday.org/issues/issue10_4/birdsall/index.html, 7.03.2008.

California Internet Voting Task Force. 2000. A Report on the Feasibility of Internet Voting. California Secretary of State Bill Jones. http://www.sos.ca.gov/elections/ ivote/final_report.pdf, 4.05.2009.

Holzer Marc, Kim Seang-Tae. 2008. Digital Governance in Municipalities Worldwide. National Center for Public Performance, Newark. http://andromeda. rutgers.edu/ egovinst/Website/PDFs/100\%20City\%20Survey\%202007\%20 (Full\%20Report).pdf, 4.05.2009.

Ito Joichi. 2004. Weblogs and Emergent Democracy. http://joi.ito.com/static/emergentdemocracy.html, 3.05.2009.

Leadership in Customer Service: New Expectations, New Experiences. „Accenture”. 
2005. http://www.accenture.com/NR/rdonlyres/F45CE4C8-9330-4450-BB4AAF4E265C88D4/0/leadership_cust.pdf, 28.04.2009.

Rainie Lee, Cornfield Michael, Horrigan John. 2005. The Internet and Campaign 2004. The Pew Research Center. http://www.pewinternet.org, 23.10.2007.

Rainie Lee, Horrigan John. 2007. Elections 2006 Online. The Pew Research Center. http://www.pewinternet.org, 23.10.2007.

Trechsel Alexander, Schwerdt Guido, Breuer Fabian, Alvarez Michael, Hall Thad. 2007. Internet Voting in the March 2007 Parliamentary Elections in Estonia. Report for the Council of Europe. http://www.vote.caltech.edu/drupal/files/report/internet_voting_estonia_2007.pdf, 29.04.2009.

United Nations E-Government Survey. 2008. From E-Government to Connected Governance. United Nations. New York. http://unpan1.un.org/intradoc/groups/ public/documents/UN/UNPAN028607.pdf, 4.05.2009.

Voter's Guide to Electronic Voting. 2004. Verified Voting Foundation. http://www.verifiedvoting.org/downloads/20041015.votersguide.pdf, 4.05.2009. 